\title{
Effect of dolomite fertilization on nutritional status of seedlings and soil properties in forest nursery
}

\author{
Jarosław Lasota ${ }^{1}$, Marta Kempf ${ }^{1 *}$, Piotr Kempf ${ }^{1,2}$, Ewa Błońska ${ }^{1}$ \\ ${ }^{1}$ University of Agriculture in Krakow, Faculty of Forestry, Department of Ecology and Silviculture, 29 Listopada Str. 46, 31-425 Kraków, Poland \\ ${ }^{2}$ Kraków Municipal Greenspace Authority, Reymonta Str. 20, 30-059 Kraków, Poland \\ * M. Kempf, PhD, m.kempf@ur.krakow.pl, ORCID iD: https://orcid.org/0000-0002-0564-0950
}

\begin{abstract}
Received: 26.06.2020

Accepted: 07.01.2021

Associated editor: P. Sewerniak

\section{Keywords}

Enzyme activity

Fertilization

Dolomite

Soil properties

Manganese toxicity

The aim of the study was to determine the effect of dolomite fertilization on the properties of soils in the forest nursery and to determine the nutritional status of two species seedlings: the common beech (Fagus sylvatica L.) and pedunculate oak (Quercus robur L.) The study was carried out in the area of a forest nursery in the Polanów Forest District (northern Poland). Mineral fertilization with dolomite in the amount of $2200 \mathrm{~kg} / \mathrm{ha}$ was applied on the experimental plots. One and two years after the fertilization, soil properties were evaluated and the the amount of nutrients in the leavesof seedlings was determined. The $\mathrm{pH}, \mathrm{C}$ and $\mathrm{N}$ content, content of exchangeable basic cations, mineral nitrogen forms and enzymatic activity were determined in the soil samples. The content of macro and microelements was determined in the leaves of the tested species. The study conducted confirmed the beneficial effect of applied dolomite fertilization. Fertilization reduced acidification, increased Mg content and improved enzyme activity. In the case of both species, an improvement in the nutritional status was recorded one and two years after fertilization. A positive effect of the conducted fertilization was a decrease in the manganese content in beech and oak leaves. There was a significant correlation between the content of manganese in the leaves of the studied species and the content of magnesium in the soils. The enzymatic activity reacts to changes in the soil environment caused by dolomite fertilization.
\end{abstract}

\section{Introduction}

The soil sorption complex serves as a reservoir of nutrients that are released into the soil solution from where they are available to plants. The appropriate soil $\mathrm{pH}$, cations exchange capacity and base saturation must be maintained for optimal macro and microelements uptake in forest nurseries (van den Driessche, 1984). In forest nurseries, especially those on a larger scale, intensive and long-term use leads to the risk of so-called "soil fatigue” (Szołtyk, 2006). Biological imbalance, also manifested in the unfavorable domination of bacteria over mycorrhizal fungi (Sienkiewicz, 2009), subsequently leads to a reduction in the quality of seedlings being produced (Aleksandrowicz-Trzcińska, 2004). In order to prevent this, a number of activities are carried out to improve the properties of the substrate in forest nurseries (Szołtyk and Hilszczańska, 2003). One of the basic revitalization treatments for soil is simply regulating its $\mathrm{pH}$, which consists of acidification or liming. Acidification is necessary when the longterm application of organic materials with high $\mathrm{pH}$ values (e.g. low peat, excessively limed compost, multi-component fertilizers) leads to soil alkalization (Szołtyk, 2006). In the second case, when soil acidifies due to the leaching of calcium into the deeper layers, its absorption by plants, or its binding by certain mineral fertilizers, liming is necessary.

Acidity determines many processes taking place in soils, affects the processes of soil organic matter transformation, nutrient circulation, development of living organisms, resulting in the amount and quality of biomass obtained (Błońska et al., 2016b). Excessively low pH can be dangerous for plants as it limits the availability of nutrients, and additionally leads to excessive absorption of aluminum (Al), manganese (Mn), and ferrum Fe, which may have a toxic effect on plants (Walendziak and Szołtyk, 1992). Acidification is associated with alkaline cations leaching from soils, especially calcium (Ca) and magnesium $(\mathrm{Mg})$. Alkaline cations are replaced by aluminum, hydrogen and manganese, which appear in soil solution in excessive amounts as the $\mathrm{pH}$ decreases. Mineral fertilization, especially liming, is used to reduce soil acidity by increasing $\mathrm{pH}$ and concentration of exchangeable calcium and magnesium (Błońska et al., 2017; Januszek et al., 2020; Saarsalmi et al., 2014, 2011). The use of liming by changing the $\mathrm{pH}$ of the soil plays a key role in regulating the mineralization of organic matter, $\mathrm{N}$ transformation, nitrification and denitrification (Bolan et al., 2011). Liming of acidic soils has a positive effect on microbiological biomass (Badalucco 
et al., 1992), fertilization usually strongly favors the accumulation of organic residues which increases soil microbiological biomass (Luo et al., 2015). The structure and functions of microbial communities are key drivers of soil biogeochemical cycles and general soil quality (Nannipieri et al., 2018). Measurements of the activity of extracellular enzymes involved in the circulation of nutrients originating from organic compounds provide information about the biogeochemical cycles (Adamczyk et al., 2014). Several common hydrolytic enzymes contribute to the $C$ cycle ( $\beta$-D-cellobiosidase, $\beta$-Glucosidase, $\beta$-Xylosidase), $\mathrm{N}$ cycle (N-acetyl- $\beta$-Glucominidase), P cycle (phosphatase) and S cycle (arylsulphatase), their main function is degradation of cellulose, hemicelluloses and chitin (Parvin et al., 2018). Hu et al. (2014) results suggest that a balanced application of fertilizer nutrients has positive effects on multiple soil chemical parameters, which in turn enhances enzyme activity.

Differences in the reaction of the soil to liming can be caused by the amount, form and frequency of application, as well as the composition of the applied fertilizer, and other factors such as climate, environmental conditions, type of humus and chemical properties of the soil can strongly influence the effect of liming treatments (Schaaf and Hüttl, 2006). In Polish forest nurseries, it is recommended to use dolomite lime containing $20 \% \mathrm{MgO}$, which is supposed to compensate for the deficiencies of magnesium common in nursery production (Szołtyk, 2006).

So far, few studies have been conducted on the effect of dolomite fertilization on the properties of nursery soils and the content of micro and macro nutrients in the assimilation apparatus of tree seedlings. The aim of our study was to determine the effect of dolomite fertilization on the properties of soils in forest nurseries. The basic properties of soils and the activity of extracellular enzymes involved in the transformation of C, N, P and S were used to assess the effect of fertilization on nutritional status of seedlings. Additionally, the amount of nutrients in the leaves of seedlings as a result of dolomite fertilization was determined.

\section{Materials and methods}

\subsection{Study area and experimental design}

The study was carried out in the area of a forest nursery in the Polanów Forest District (northern Poland). The study area is characterized by the following meteorological conditions: the average length of the growing season is 230 days, the average temperature during the growing season is $13^{\circ} \mathrm{C}$ and the average precipitation during this period is $300 \mathrm{~mm}$. The study areas were dominated by Cambisols (IUSS Working Group WRB, 2015). The study covered two species, i.e., common beech (Fagus sylvatica L.) and pedunculate oak (Quercus robur L.).
Twelve plots of dimensions 20x10 m were selected for the study. Soils on the research plots were characterized by a similar share of sand fraction $45 \%$, silt $49 \%$ and clay $6 \%$. Six plots were grown with beech, on the next six with oaks. Mineral fertilization with dolomite in the amount of $2200 \mathrm{~kg} / \mathrm{ha}$ was applied on three plots with beech and three plots with oak (Table 1). The applied fertilizer was characterized by granulation up to $2 \mathrm{~mm}$. The remaining 6 plots were control plots ( 3 control plots with beech and 3 control plots with oak). Fertilization was carried out in October 2017, and soil and plant material samples for laboratory analyses were taken in August 2018 and 2019. The fertilizer in the form of granules was spread evenly over the test plots. From each plot, soil samples from five points for analyses were collected. Soil samples were taken from a depth of 0-15 cm. The oak and beech seeds were sown pointwise. In addition, plant material for laboratory analysis was collected from each plot. Oak and beech leaves were taken from 30 seedlings on each research plot. One-year (2018) and two-year (2019) seedlings were collected for laboratory analyzes. The seedlings for the analyzes were selected randomly from the research plots. All leaves were separated from each seedling, dried and ground.

\subsection{Laboratory analysis}

In the soil samples, the particle-size distribution was determined using the laser diffraction (Analysette 22, Fritsch, Idar-Oberstein, Germany), $\mathrm{pH}$ was analyzed in distilled water using the potentiometric method, as well as the content of total nitrogen $(\mathrm{N})$ and organic carbon $(\mathrm{C})$ content were measured using LECO CNS True Mac Analyzer (Leco, St. Joseph, MI, USA), including the calculation of the $\mathrm{C} / \mathrm{N}$ ratio. Exchangeable calcium, potassium, magnesium were determined after extraction in $1 \mathrm{M}$ ammonium acetate by an ICP (ICP-OES Thermo iCAP 6500 DUO, Thermo Fisher Scientific, Cambridge, U.K.). In the samples with natural moisture the forms of mineral nitrogen $\mathrm{NH}_{4}-\mathrm{N}$ and $\mathrm{NO}_{3}-$ $\mathrm{N}$ in $2 \mathrm{M} \mathrm{KCl}$ soil extracts by FIAstar 5000 were determined.

For the determination of enzymatic activity fresh samples of natural moisture were sieved through a sieve $(\varnothing 2 \mathrm{~mm})$ and stored at $4^{\circ} \mathrm{C}$ until analysis. The activity of extracellular enzymes ( $\beta$-glucosidase (BG); $\beta$-D-cellobiosidase (CB); xylanase (XYL); N-acetyl- $\beta$ D-glucosaminidase (NAG); phosphatase (PH) and arylsulphatase (SP)) were determined using fluorogenically labelled substrates (Pritsch et al., 2004; Sanaullah et al., 2016; Turner, 2010) (Pritsch et al., 2004; Turner 2010; Sannaullah et al., 2016). Fluorescence was measured on a multi-detection plate reader (SpectroMax) with excitation at $355 \mathrm{~nm}$ and emission at $460 \mathrm{~nm}$ wavelengths.

In the leaves samples, the concentration of macro and microelements was determined by an ICP (ICP-OES Thermo iCAP 6500 DUO, Thermo Fisher Scientific, Cambridge, U.K.). Dried samples of leaves were mineralized in a mixture of $\mathrm{HNO}_{3}$ and

Table 1

The chemical composition of dolomite used for fertilization

\begin{tabular}{llllllll}
\hline $\begin{array}{l}\mathrm{Ca} \\
\%\end{array}$ & $\mathrm{Mg}$ & $\mathrm{Fe}$ & $\mathrm{Mn}$ & $\mathrm{Mo}$ & $\mathrm{B}$ & $\mathrm{Zn}$ & $\mathrm{Cu}$ \\
\hline 21.5 & 10.9 & 1.5 & 0.1 & 0.02 & 0.02 & 0.005 & 0.003 \\
\hline
\end{tabular}


$\mathrm{HClO}_{4}$ (3:1). Carbon (C) and nitrogen (N) in the leaves samples were measured with an elemental analyzer (LECO CNS TrueMac Analyzer (Leco, St. Joseph, MI, USA)).

\subsection{Statistical analysis}

The normality of a variable distribution was checked. Tukey HSD test was used to evaluate the differences in the mean values of the soil properties and nutrients content in the assimilation apparatus between variants treatments. Spearman's correlation coefficients for the activity of soil enzymes, selected soil characteristics and nutrition of seedlings were calculated. The principal component analysis (PCA) method was used to evaluate the relationships between soil properties and seedling characteristics. Differences with $\mathrm{P}<0.05$ were considered statistically significant. All analyses were performed using Statistica 12 software (StatSoft 2012).

\section{Results}

Higher $\mathrm{pH}$ was recorded in soils fertilized with dolomite in the first and second year of the study (Table 2). In the first year after dolomite application, significantly higher $\mathrm{pH}$ was recorded on plots with oak. In the second year of the study, significantly higher $\mathrm{pH}$ was recorded on plots with oak and beech (Table 2). In the case of carbon content, the effect of fertilization was recorded in the first year of the study in soils with oak. No significant increase in nitrogen content was recorded in soils fertilized with dolomite (Table 2). As a result of the fertilization, a significant increase in the content of alkaline cations, especially calcium and magnesium, was recorded. In the case of calcium, a significant increase in the content was recorded in plots with oak and beech in the second year of the study, and in the case of magnesium, a significant increase in the content was recorded both in the first and second year of the study, in soils with oak and beech (Table 2). In the case of phosphorus content, the effect of fertilization was less visible. The ammonium nitrogen content did not change after fertilization with dolomite. In the case of nitrate nitrogen, an increase in the content was recorded in the first year of the study in soils of beech plots (Table 2).

In case of enzymatic activity, the effect of fertilization is visible in the first and second year of the study. In the first year of the study there was no statistically significant increase in the activity of the enzymes studied (Table 3 ). In the second year of the study, the differences between the enzymatic activity of fertilized and control plot soils were more pronounced. In the case of BG, CB and NAG, a statistically significantly higher activity was recorded in the fertilized soils in the second year of the study, regardless of the species (Table 3).

The effect of fertilization is visible in the nutrition of oak and beech seedlings (Table 4). In the case of carbon and nitrogen, there was no statistically significant increase in the assimilation apparatus of the studied species. A similar effect was observed in the case of calcium, potassium, phosphorus and copper contents. A significant increase as a result of dolomite fertilization was recorded for magnesium content. A higher magnesium content was recorded in beech and oak leaves growing on soils of fertilized plots (Table 4). Manganese content in leaves of the tested species decreased as a result of the fertilization. In the case of beech, a significantly lower manganese content was recorded in the first and second year of the study, in the case of oak, the manganese content was significantly lower in the second year of the study (Table 4).

The enzymatic activity of the soils studied strongly positively correlated with soil $\mathrm{pH}$ and nitrate nitrogen content in the soil (Table 5). Additionally, a strong, positive relationship between the majority of the studied enzymes and the content of magnesium in leaves of the studied species was recorded. In the case of $\mathrm{CB}$ and XYL activity, the relationship with potassium content in leaves was recorded (Table 5). Figure 1 shows the correlation between the content of manganese in the leaves of the tested species and the content of magnesium in soils. The PCA analysis confirms the effect of dolomite fertilization on the

Table 2

Basic properties of the studied soils

\begin{tabular}{|c|c|c|c|c|c|c|c|c|c|c|c|c|}
\hline $\begin{array}{l}\text { Year of } \\
\text { study }\end{array}$ & $\begin{array}{l}\text { Study } \\
\text { variant }\end{array}$ & $\mathrm{pH} \mathrm{H}_{2} \mathrm{O}$ & $\mathrm{pH} \mathrm{KCl}$ & $\begin{array}{l}\mathrm{C} \\
\%\end{array}$ & $\mathrm{~N}$ & $\mathrm{C} / \mathrm{N}$ & $\begin{array}{l}\mathrm{Ca} \\
\mathrm{mg} \cdot 100 \mathrm{~g}^{-1}\end{array}$ & $\mathrm{Mg}$ & $\mathrm{K}$ & $\begin{array}{l}\mathrm{P} \\
\mathrm{mg} \cdot \mathrm{kg}^{-1}\end{array}$ & $\mathrm{~N}-\mathrm{NH}_{4}$ & $\mathrm{~N}-\mathrm{NO}_{3}$ \\
\hline \multirow[t]{4}{*}{ I } & D Beech & $5.07 \pm 0.05^{\mathrm{a}}$ & $4.07 \pm 0.05^{\mathrm{a}}$ & $2.06 \pm 0.17^{\mathrm{a}}$ & $0.15 \pm 0.01^{\mathrm{a}}$ & $14.1 \pm 0.1^{\mathrm{a}}$ & $23.0 \pm 1.9^{a}$ & $2.6 \pm 0.3^{a}$ & $7.7 \pm 0.2^{\mathrm{a}}$ & $81.9 \pm 27.9^{b}$ & $2.1 \pm 0.1^{\mathrm{a}}$ & $11.8 \pm 0.1^{\mathrm{a}}$ \\
\hline & C Beech & $4.92 \pm 0.13^{\mathrm{a}}$ & $3.89 \pm 0.10^{\mathrm{b}}$ & $2.36 \pm 0.22^{\mathrm{a}}$ & $0.16 \pm 0.02^{\mathrm{a}}$ & $14.7 \pm 0.5^{\mathrm{a}}$ & $21.8 \pm 0.6^{\mathrm{a}}$ & $1.2 \pm 0.1^{b}$ & $7.5 \pm 0.3^{\mathrm{a}}$ & $128.4 \pm 6.0^{\mathrm{a}}$ & $2.2 \pm 0.0^{\mathrm{a}}$ & $12.1 \pm 0.4^{\mathrm{a}}$ \\
\hline & D Oak & $5.13 \pm 0.05^{\mathrm{a}}$ & $4.19 \pm 0.14^{\mathrm{a}}$ & $1.99 \pm 0.03^{b}$ & $0.14 \pm 0.01^{\mathrm{a}}$ & $14.7 \pm 1.1^{\mathrm{a}}$ & $22.4 \pm 2.8^{\mathrm{a}}$ & $2.4 \pm 0.2^{\mathrm{a}}$ & $9.4 \pm 0.3^{\mathrm{a}}$ & $97.6 \pm 14.0^{\mathrm{a}}$ & $3.8 \pm 1.2^{\mathrm{a}}$ & $13.9 \pm 1.1^{\mathrm{a}}$ \\
\hline & C Oak & $4.81 \pm 0.10^{\mathrm{b}}$ & $3.81 \pm 0.07^{\mathrm{b}}$ & $2.44 \pm 0.12^{\mathrm{a}}$ & $0.16 \pm 0.01^{\mathrm{a}}$ & $15.7 \pm 1.0^{\mathrm{a}}$ & $20.5 \pm 0.7^{a}$ & $1.3 \pm 0.1^{b}$ & $7.8 \pm 0.3^{\mathrm{a}}$ & $108.1 \pm 18.8^{a}$ & $2.9 \pm 0.6^{\mathrm{a}}$ & $12.4 \pm 1.5^{\mathrm{a}}$ \\
\hline \multirow[t]{4}{*}{ II } & D Beech & $5.30 \pm 0.10^{\mathrm{a}}$ & $4.20 \pm 0.10^{\mathrm{a}}$ & $2.20 \pm 0.01^{\mathrm{a}}$ & $0.10 \pm 0.00^{\mathrm{a}}$ & $15.5 \pm 0.2^{\mathrm{a}}$ & $36.5 \pm 8.1^{\mathrm{a}}$ & $3.6 \pm 0.5^{\mathrm{a}}$ & $7.9 \pm 0.1^{\mathrm{a}}$ & $76.5 \pm 9.9^{b}$ & $6.5 \pm 0.4^{\mathrm{a}}$ & $25.4 \pm 4.2^{\mathrm{a}}$ \\
\hline & C Beech & $5.00 \pm 0.17^{b}$ & $4.00 \pm 0.08^{b}$ & $2.30 \pm 0.14^{\mathrm{a}}$ & $0.10 \pm 0.01^{\mathrm{a}}$ & $15.7 \pm 0.4^{\mathrm{a}}$ & $21.0 \pm 5.2^{\mathrm{b}}$ & $1.5 \pm 0.3^{b}$ & $6.2 \pm 0.5^{b}$ & $107.2 \pm 7.7^{\mathrm{a}}$ & $6.9 \pm 0.3^{\mathrm{a}}$ & $7.5 \pm 3.7^{\mathrm{b}}$ \\
\hline & D Oak & $5.20 \pm 0.07^{\mathrm{a}}$ & $4.20 \pm 0.11^{\mathrm{a}}$ & $2.33 \pm 0.09^{a}$ & $0.16 \pm 0.02^{\mathrm{a}}$ & $14.3 \pm 0.7^{\mathrm{a}}$ & $32.3 \pm 5.1^{\mathrm{a}}$ & $5.0 \pm 0.3^{\mathrm{a}}$ & $8.6 \pm 0.3^{a}$ & $97.3 \pm 11.4^{\mathrm{a}}$ & $7.8 \pm 0.8^{\mathrm{a}}$ & $18.4 \pm 5.2^{\mathrm{a}}$ \\
\hline & C Oak & $4.82 \pm 0.17^{\mathrm{b}}$ & $3.94 \pm 0.14^{\mathrm{b}}$ & $2.24 \pm 0.07^{a}$ & $0.15 \pm 0.01^{\mathrm{a}}$ & $15.4 \pm 0.8^{a}$ & $14.1 \pm 3.1^{b}$ & $1.8 \pm 0.4^{\mathrm{b}}$ & $5.4 \pm 0.3^{b}$ & $101.6 \pm 6.2^{\mathrm{a}}$ & $6.4 \pm 0.4^{\mathrm{a}}$ & $10.5 \pm 2.8^{\mathrm{a}}$ \\
\hline
\end{tabular}

mean \pm SD; D - plots after fertilization; C - control plots; small letters in the upper index of the mean values mean significant differences between study variants

średnia \pm SD; D - działki po nawożeniu; C - wykresy kontrolne; małe litery w górnym indeksie średnich wartości oznaczają znaczne różnice między wariantami badania 
Table 3

Enzyme activity of study soils

\begin{tabular}{|c|c|c|c|c|c|c|c|}
\hline $\begin{array}{l}\text { Year of } \\
\text { study }\end{array}$ & $\begin{array}{l}\text { Study } \\
\text { variant }\end{array}$ & $\begin{array}{l}\text { BG } \\
\text { nmol MUB'g }\end{array}$ & $\begin{array}{l}\mathrm{CB} \\
\mathrm{h}^{-1}\end{array}$ & XYL & NAG & $\mathrm{PH}$ & SP \\
\hline \multirow[t]{4}{*}{ I } & D Beech & $33.51 \pm 8.36^{\mathrm{a}}$ & $6.00 \pm 1.12^{\mathrm{a}}$ & $3.38 \pm 0.67^{a}$ & $20.46 \pm 6.76^{\mathrm{a}}$ & $275.21 \pm 48.13^{a}$ & $1.16 \pm 0.61^{\mathrm{a}}$ \\
\hline & C Beech & $26.17 \pm 5.96^{\mathrm{a}}$ & $4.91 \pm 0.42^{\mathrm{a}}$ & $2.79 \pm 0.88^{\mathrm{a}}$ & $16.92 \pm 2.56^{\mathrm{a}}$ & $257.36 \pm 52.26^{\mathrm{a}}$ & $0.69 \pm 0.27^{\mathrm{a}}$ \\
\hline & D Oak & $27.37 \pm 8.36^{\mathrm{a}}$ & $7.04 \pm 1.68^{\mathrm{a}}$ & $4.14 \pm 1.13^{\mathrm{a}}$ & $20.93 \pm 3.65^{\mathrm{a}}$ & $327.05 \pm 121.81^{\mathrm{a}}$ & $0.95 \pm 0.25^{a}$ \\
\hline & C Oak & $26.11 \pm 9.14^{\mathrm{a}}$ & $5.36 \pm 1.56^{\mathrm{a}}$ & $3.51 \pm 0.68^{a}$ & $15.40 \pm 4.67^{\mathrm{a}}$ & $197.02 \pm 17.38^{\mathrm{a}}$ & $0.75 \pm 0.20^{\mathrm{a}}$ \\
\hline \multirow[t]{4}{*}{ II } & D Beech & $42.24 \pm 4.62^{\mathrm{a}}$ & $8.53 \pm 1.89^{\mathrm{a}}$ & $3.92 \pm 1.03^{\mathrm{a}}$ & $25.18 \pm 4.46^{\mathrm{a}}$ & $379.16 \pm 68.89^{\mathrm{a}}$ & $1.37 \pm 0.65^{\mathrm{a}}$ \\
\hline & C Beech & $28.79 \pm 6.39^{b}$ & $5.06 \pm 0.86^{\mathrm{b}}$ & $2.45 \pm 1.18^{\mathrm{a}}$ & $15.96 \pm 4.29^{b}$ & $223.91 \pm 106.99^{a}$ & $0.66 \pm 0.26^{\mathrm{a}}$ \\
\hline & D Oak & $38.08 \pm 5.85^{\mathrm{a}}$ & $9.64 \pm 2.90^{\mathrm{a}}$ & $4.22 \pm 1.47^{\mathrm{a}}$ & $28.07 \pm 6.48^{\mathrm{a}}$ & $391.01 \pm 132.17^{a}$ & $1.95 \pm 1.04^{\mathrm{a}}$ \\
\hline & C Oak & $25.18 \pm 4.22^{\mathrm{b}}$ & $5.21 \pm 0.32^{\mathrm{b}}$ & $2.60 \pm 1.13^{a}$ & $16.07 \pm 3.80^{\mathrm{b}}$ & $203.77 \pm 43.95^{\mathrm{a}}$ & $0.87 \pm 0.72^{\mathrm{a}}$ \\
\hline
\end{tabular}

Explanations: mean \pm SD; D - plots after fertilization; $C$ - control plots; CB - $\beta$-D-cellobiosidase, XYL - xylanase, NAG - Nacetyl- $\beta$-D-glucosaminidase, BG - $\beta$-glucosidase, $\mathrm{PH}$ - phosphatase and SP - arylosulphatase; small letters in the upper index of the mean values mean significant differences between study variants

Table 4

The content of macroelements and selected microelements in beech and oak seedlings

\begin{tabular}{|c|c|c|c|c|c|c|c|c|c|}
\hline $\begin{array}{l}\text { Year of } \\
\text { study }\end{array}$ & $\begin{array}{l}\text { Study } \\
\text { variant }\end{array}$ & $\begin{array}{l}\text { C } \\
\text { \% d.m. }\end{array}$ & $\mathrm{N}$ & $\mathrm{Ca}$ & $\mathrm{Mg}$ & $\mathrm{K}$ & $\mathrm{P}$ & $\begin{array}{l}\text { Mn } \\
\text { mg.kg-1 d.m. }\end{array}$ & $\mathrm{Cu}$ \\
\hline \multirow{4}{*}{ I } & D Beech & $45.95 \pm 1.05^{\mathrm{a}}$ & $2.21 \pm 0.12^{\mathrm{a}}$ & $0.70 \pm 0.10^{\mathrm{a}}$ & $0.10 \pm 0.03^{a}$ & $0.67 \pm 0.02^{\mathrm{a}}$ & $0.17 \pm 0.02^{\mathrm{a}}$ & $2323.00 \pm 623.05^{b}$ & $15.86 \pm 0.19^{a}$ \\
\hline & C Beech & $46.75 \pm 0.59^{a}$ & $2.17 \pm 0.05^{\mathrm{a}}$ & $0.64 \pm 0.08^{\mathrm{a}}$ & $0.06 \pm 0.01^{\mathrm{a}}$ & $0.60 \pm 0.03^{\mathrm{b}}$ & $0.16 \pm 0.01^{\mathrm{a}}$ & $5888.25 \pm 239.75^{a}$ & $14.81 \pm 1.30^{\mathrm{a}}$ \\
\hline & D Oak & $46.41 \pm 2.12^{\mathrm{a}}$ & $2.36 \pm 0.12^{\mathrm{a}}$ & $0.50 \pm 0.03^{\mathrm{a}}$ & $0.13 \pm 0.02^{\mathrm{a}}$ & $0.82 \pm 0.04^{\mathrm{a}}$ & $0.21 \pm 0.01^{\mathrm{a}}$ & $1651.00 \pm 240.60^{\mathrm{a}}$ & $16.81 \pm 0.19^{\mathrm{a}}$ \\
\hline & C Oak & $46.31 \pm 0.59^{\mathrm{a}}$ & $2.22 \pm 0.03^{\mathrm{a}}$ & $0.60 \pm 0.07^{\mathrm{a}}$ & $0.09 \pm 0.01^{\mathrm{b}}$ & $0.76 \pm 0.13^{\mathrm{a}}$ & $0.20 \pm 0.01^{\mathrm{a}}$ & $1940.50 \pm 302.42^{\mathrm{a}}$ & $15.13 \pm 1.30^{\mathrm{a}}$ \\
\hline \multirow{4}{*}{ II } & D Beech & $46.18 \pm 0.70^{\mathrm{a}}$ & $2.19 \pm 0.12^{\mathrm{a}}$ & $0.55 \pm 0.08^{\mathrm{a}}$ & $0.24 \pm 0.05^{\mathrm{a}}$ & $0.81 \pm 0.02^{\mathrm{a}}$ & $0.19 \pm 0.01^{\mathrm{a}}$ & $904.08 \pm 410.45^{\mathrm{b}}$ & $16.52 \pm 1.76^{\mathrm{a}}$ \\
\hline & C Beech & $47.27 \pm 0.64^{\mathrm{a}}$ & $1.95 \pm 0.13^{\mathrm{a}}$ & $0.72 \pm 0,10^{\mathrm{a}}$ & $0.08 \pm 0.01^{\mathrm{b}}$ & $0.71 \pm 0.08^{\mathrm{a}}$ & $0.17 \pm 0.01^{\mathrm{a}}$ & $5522.00 \pm 931.11^{\mathrm{a}}$ & $16.70 \pm 2.33^{\mathrm{a}}$ \\
\hline & D Oak & $46.78 \pm 1.14^{\mathrm{a}}$ & $2.28 \pm 0.12^{\mathrm{a}}$ & $0.53 \pm 0.07^{\mathrm{a}}$ & $0.28 \pm 0.13^{\mathrm{a}}$ & $0.79 \pm 0.05^{\mathrm{a}}$ & $0.21 \pm 0.02^{\mathrm{a}}$ & $740.63 \pm 137.72^{\mathrm{b}}$ & $20.56 \pm 1.45^{a}$ \\
\hline & C Oak & $46.50 \pm 1.80^{\mathrm{a}}$ & $2.16 \pm 0.13^{\mathrm{a}}$ & $0.55 \pm 0.05^{\mathrm{a}}$ & $0.11 \pm 0.01^{\mathrm{b}}$ & $0.60 \pm 0.16^{\mathrm{a}}$ & $0.20 \pm 0.00^{\mathrm{a}}$ & $2184.67 \pm 129.22^{\mathrm{a}}$ & $19.53 \pm 1.88^{\mathrm{a}}$ \\
\hline
\end{tabular}

mean \pm SD; D - plots after fertilization; C - control plots; small letters in the upper index of the mean values mean significant differences between study variants

Table 5

Correlations between the activity of soil enzymes and selected soil characteristics and nutrition of seedlings

\begin{tabular}{llllllllllll}
\hline & $\mathrm{pH} \mathrm{H}_{2} \mathrm{O}$ & $\mathrm{C}$ & $\mathrm{N}$ & $\mathrm{N}^{-\mathrm{NO}_{3}}$ & $\mathrm{~N}-\mathrm{NH}_{4}$ & $\mathrm{~N}_{\mathrm{L}}$ & $\mathrm{Mg}_{\mathrm{L}}$ & $\mathrm{K}_{\mathrm{L}}$ & $\mathrm{P}_{\mathrm{L}}$ & $\mathrm{Ca}_{\mathrm{L}}$ \\
\hline $\mathrm{BG}$ & $0.783^{*}$ & 0.080 & 0.309 & $0.507^{*}$ & 0.313 & 0.135 & $0.544^{*}$ & 0.258 & 0.056 & 0.083 \\
$\mathrm{CB}$ & $0.817^{*}$ & 0.052 & 0.241 & $0.667^{*}$ & 0.307 & 0.401 & $0.803^{*}$ & $0.541^{*}$ & $0.413^{*}$ & -0.297 \\
$\mathrm{XYL}$ & 0.334 & -0.155 & -0.093 & 0.298 & 0.039 & 0.186 & 0.297 & $0.432^{*}$ & 0.304 & -0.373 \\
$\mathrm{NAG}$ & $0.641^{*}$ & -0.104 & 0.198 & $0.632^{*}$ & 0.214 & $0.487^{*}$ & $0.694^{*}$ & 0.310 & 0.311 & -0.214 \\
$\mathrm{PH}$ & $0.661^{*}$ & -0.342 & 0.041 & $0.689^{*}$ & 0.049 & 0.370 & $0.478^{*}$ & 0.136 & 0.097 & 0.040 \\
$\mathrm{SP}$ & $0.811^{*}$ & -0.002 & 0.311 & $0.658^{*}$ & 0.230 & 0.256 & $0.584^{*}$ & 0.278 & 0.217 & -0.018 \\
\hline
\end{tabular}

$* p<0.05 ; \mathrm{N}_{\mathrm{L}}, \mathrm{Mg}_{\mathrm{L}}, \mathrm{K}_{\mathrm{L}}, \mathrm{P}_{\mathrm{L}}, \mathrm{Ca}_{\mathrm{L}}-$ content in the leaves of the tested seedlings

properties of the soils studied and on the nutrition of beech and oak seedlings (Fig. 2 and 3). In the case of beech plots, the PCA analysis explains more than $69 \%$ of the variability of the features tested. Soils of fertilized plots clearly separate from those of control plots. Soils of control plots without fertilization are characterized by high manganese content, low $\mathrm{pH}$, lower con- tent of nutrients, especially magnesium (Fig. 2). In the case of plots with oak, the PCA analysis explains more than $69 \%$ of the variability of the features tested (Fig. 3). Similarly as in the case of plots with beech, the soils of plots fertilized with dolomite with oak clearly differ in properties compared to those of control surfaces. 
Fig. 1. Relationship between $\mathrm{Mn}\left(\mathrm{mg} \cdot \mathrm{kg}^{-1} \mathrm{~d} . \mathrm{m}\right.$.) content in seedlings leaves and $\mathrm{Mg}$ content $\left(\mathrm{mg} \cdot 100 \mathrm{~g}^{-1}\right)$ in soil

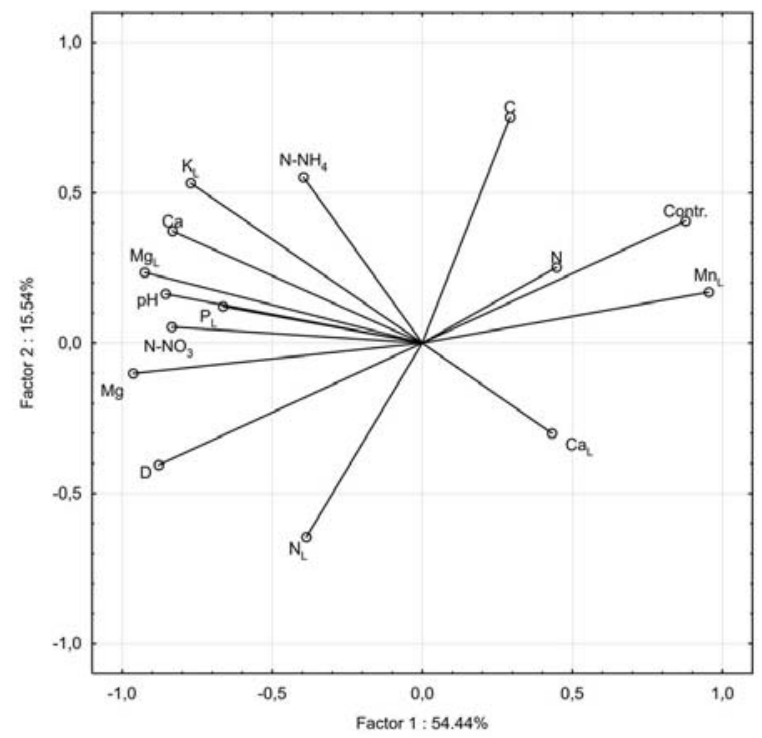

Fig. 2. PCA analysis showing the effect of dolomite fertilization on soil properties and nutrition of beech seedlings
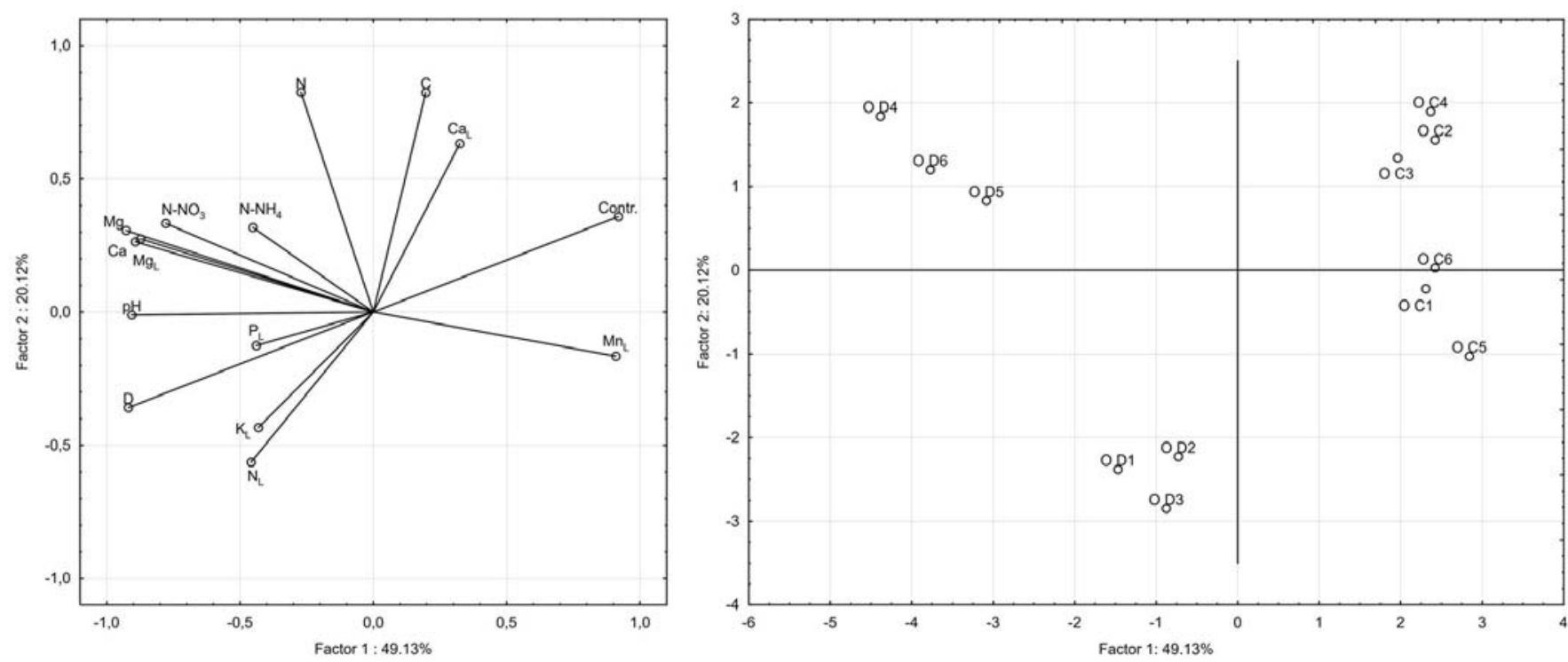

Fig. 3. PCA analysis showing the effect of dolomite fertilization on soil properties and nutrition of oak seedlings

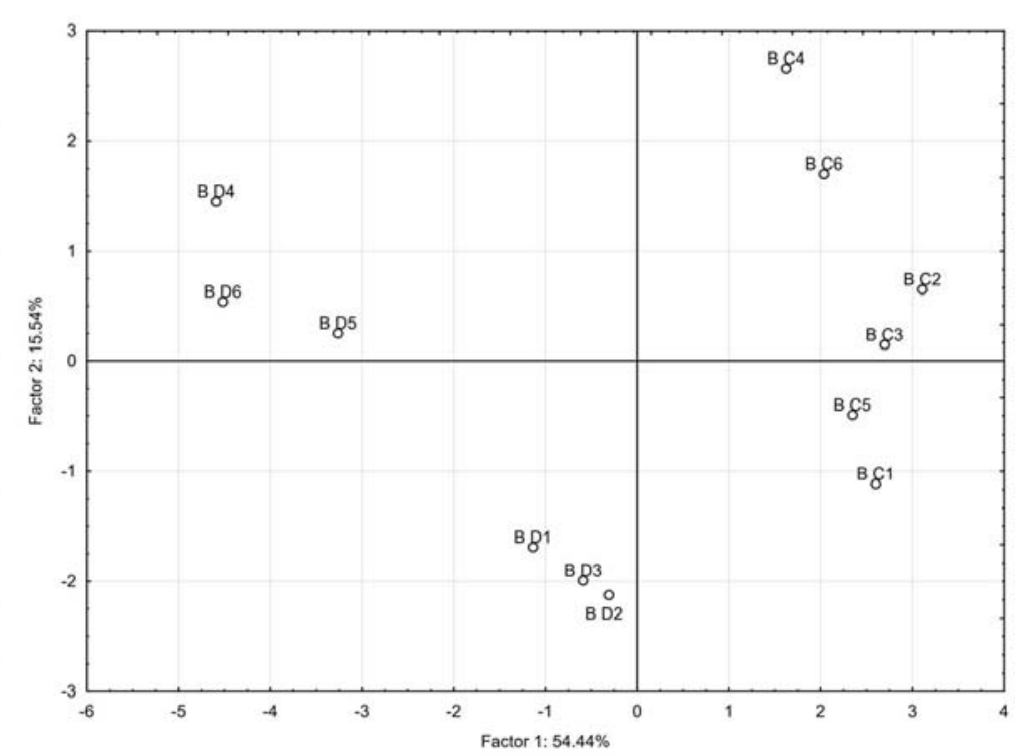

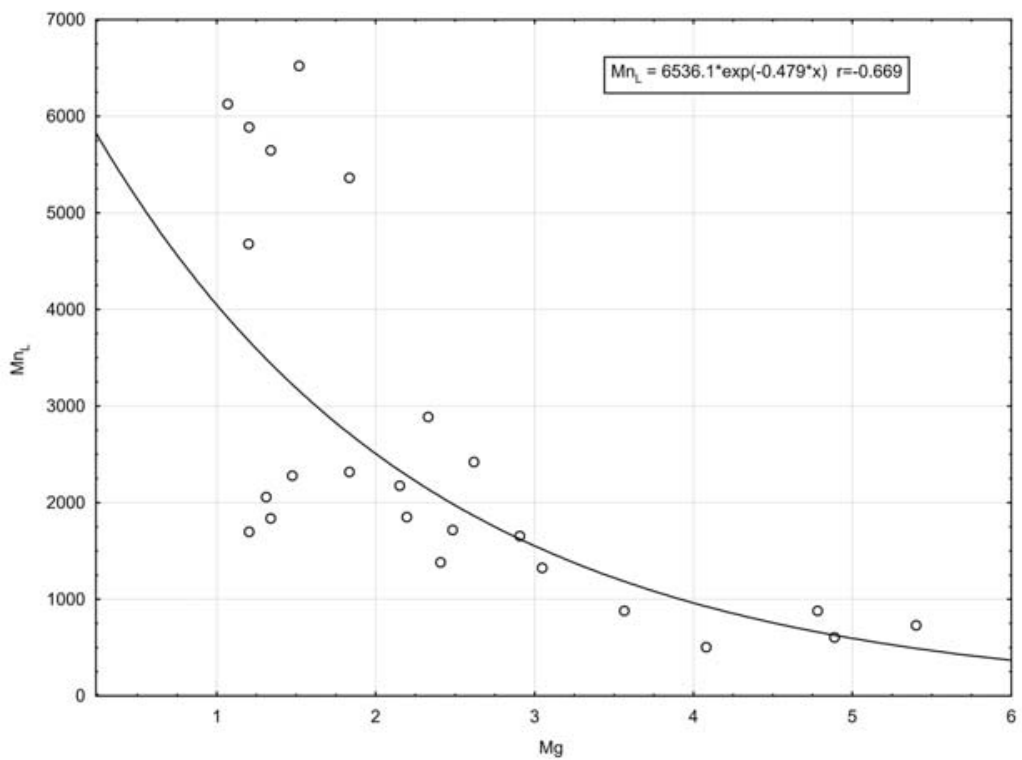




\section{Discussion}

Our study demonstrated a positive effect of dolomite fertilization on the forest nursery soil at a dose of $2200 \mathrm{~kg} / \mathrm{ha}$. The fertilization caused an increase in soil $\mathrm{pH}$ and an increase in the content of exchangeable calcium and magnesium, which became apparent in the second year after fertilizer application. Dolomite is a common mineral fertilizer, which is used to deacidify soil and increase the abundance of alkaline cations, especially magnesium (Błońska et al., 2015). Dolomite is a fertilizer from which components are slowly released (Yang et al., 2012). The use of slowly released fertilizer containing macro- and micronutrients is more favorable for improving nutrient deficiencies than rapidly soluble fertilizers (Flückiger and Braun, 1995). An additional effect of applying dolomite fertilization was an increase in soil enzymatic activity. In our study we found an increase in the activity of $\beta$-glucosidase, celobiosidase and $\mathrm{N}$ acetyl- $\beta$-glucosaminidase, which became apparent in the second year after fertilization. An increase in activity was probably caused by an increase in soil pH. Previous study proved that soil pH strongly influences enzymatic activity (Błońska et al., 2016b). Each soil enzyme has a specific $\mathrm{pH}$ range for optimal activity. At optimal pH, the enzymes are more stable. A change in the concentration of $\mathrm{H}^{+}$ions in the soil affects the dynamics of the enzymes, degradation of the substrate and change of cofactor through ionization and solubility properties (Tabatabai, 1994). Liming and the associated change in $\mathrm{pH}$ may affect the distribution of fungal and bacterial biomass in the soil (Bååth et al., 1992) and thus the enzyme activity. Previous studies proved that a decrease in $\mathrm{pH}$ leads to an increase in the percentage of fungi. The composition of the bacterial communities is closely defined by soil $\mathrm{pH}$, higher $\mathrm{pH}$ is accompanied by increasing of soil bacterial (Rousk et al., 2010). It can be assumed that another reason for an increase in enzymatic activity of the studied soils may be the influence of root systems of seedlings, which reacted positively to the applied fertilization. The studies by Gianfreda (2015) and Loeppmann et al. (2016) showed that the interaction of root systems and their secretions have a very significant impact on the activity of soil microorganisms and their enzymes, especially in rhizosphere zones. Root-related microorganisms are often considered to be the main producers of enzymes in the rhizosphere soil, but an important contribution of enzymes can originate from enzymatic proteins produced by plant roots (Chroma et al., 2002).

An additional effect of the fertilization was an increase in nitrogen mineralization, which is proved by an increase in nitrate nitrogen content on the fertilized plots with beech and a clear positive correlation of enzymatic activity with nitrate nitrogen content. The activity of $\mathrm{N}$-acetyl- $\beta$-glucosaminidase is considered as an indicator of soil nitrogen mineralization (Ekenler and Tabatabai, 2004). Its increase on plots fertilized with dolomite confirms an increase in soil nitrogen mineralization. A very important effect of the fertilization was a decrease in Mn uptake by seedlings of both beech and oak. In beech leaves, in the first year after fertilization with dolomite, the manganese content decreased about 2.5 times compared to the control, in the second year the manganese content was 6 times lower compared to the unfertilized variant. In the case of oak, the manganese content in leaves significantly decreased in the second year after fertilization and was on average 3 times lower than in the unfertilized variant. There are some reports in the literature on intensive manganese uptake under strongly acidic soil conditions (Marschner, 1995; Porter et al., 2004). In our research, statistically significant differences in the content of $\mathrm{Mn}$ in the leaves of oak and beech were noted between the fertilized variant and the control variant, where the soil was characterized by a significantly lower $\mathrm{pH}$. Mn is strongly taken up especially in a magnesium deficiency situation, which may lead, depending on the tolerance of different species, to its toxicity (Millaleo et al., 2010). The reduced uptake of Mn by the cultivated seedlings is, on the one hand, the result of reduced soil acidity, which affects the mobility and bioavailability of $\mathrm{Mn}$. On the other hand, it is an effect of increasing exchangeable magnesium content in the soil. The study conducted confirmed a strong correlation between the Mn content in the leaves of seedlings with the content of exchangeable $\mathrm{Mg}$ in the soil. After exceeding the $\mathrm{Mg}$ content over $3.0 \mathrm{mg} 100 \mathrm{~g}^{-1}$, the $\mathrm{Mn}$ content in leaves of cultivated seedlings decreased significantly.

\section{Conclusions}

The applied dolomite fertilization had a positive effect on the properties of the tested soils and the content of nutrients in leaves of the tested species. Dolomite fertilization significantly improves soil $\mathrm{pH}$ and exchangeable basic cations content in the soils. Regardless of the species of seedlings, dolomite fertilization improved the nutrition, especially of magnesium. A positive effect of the conducted fertilization was a decrease in the content of manganese in beech and oak leaves. In the assessment of the effects of soil fertilization in forest nurseries, the enzymatic activity of soils can be used, which strongly correlates with the properties of soils and the nutritional status of the young generation of trees. In forest nurseries with soils characterized by too low $\mathrm{pH}$, the application of dolomite fertilization will produce a young generation of appropriately nourished trees.

\section{References}

Adamczyk, B., Kilpeläinen, P., Kitunen, V., Smolander, A., 2014. Potential activities of enzymes involved in N, C, P and S cycling in boreal forest soil under different tree species. Pedobiologia (Jena) 57, 97-102. https://doi.org/10.1016/j.pedobi.2013.12.003

Aleksandrowicz-Trzcińska M., 2004: Kolonizacja mikoryzowa i wzrost sosny zwyczajnej (Pinus sylvestris L.) w uprawie założonej z sadzonek w różnym stopniu zmikoryzowanych. Acta Scientiarum Polonorum Silvarum Colendarum Ratio et Industria Lignaria 3, 5-15.

Bååth, E., Frostegård, Å., Fritze, H., 1992. Soil Bacterial Biomass, Activity, Phospholipid Fatty Acid Pattern, and pH Tolerance in an Area Polluted with Alkaline Dust Deposition. Applied and Environmental Microbiology 58, 4026-4031.

Badalucco, L., Grego, S., Dell’Orco, S., Nannipieri, P., 1992. Effect of liming on some chemical, biochemical, and microbiological properties of acid soils under spruce (Picea abies L.). Biology and Fertility of Soils 14, 76-83. https://doi.org/10.1007/BF00336254 
Błońska, E., Januszek, K., Małek, S., Wanic, T., 2016a. Effects of serpentinite fertilizer on the chemical properties and enzyme activity of young spruce soils. International Agrophysics 30(4), 401-414. https:// doi.org/10.1515/intag-2016-0015

Błońska, E., Lasota, J., Gruba, P., 2016b. Effect of temperate forest tree species on soil dehydrogenase and urease activities in relation to other properties of soil derived from loess and glaciofluvial sand. Ecological Research 31(5), 655-664. https://doi.org/10.1007/s11284-016-1375-6

Błońska, E., Małek, S., Januszek, K., Barszcz, J., Wanic, T., 2015. Changes in forest soil properties and spruce stands characteristics after dolomite, magnesite and serpentinite fertilization. European Journal of Forest Research 134, 981-990. https://doi.org/10.1007/s10342-015-0903-1

Błońska, E., Pająk, M., Małek, S., Januszek, K., 2017. Effects of Serpentinite Fertilization with N, P, and K Fertilizers on Soil Properties and Needle Chemistry. Communications in Soil Science and Plant Analysis 48:6, 692-704. https://doi.org/10.1080/00103624.2017.1298785

Bolan, N.S., Adriano, D.C., Kunhikrishnan, A., James, T., McDowell, R., Senesi, N., 2011. Dissolved Organic Matter. Biogeochemistry, Dynamics, and Environmental Significance in Soils. Advances in Agronomy 110, 1-75. https://doi.org/10.1016/B978-0-12-385531-2.00001-3

Chroma, L., Mackova, M., Kucerova, P., in der Wiesche, C., Burkhard, J., Macek, T., 2002. Enzymes in plant metabolism of PCBs and PAHs. Acta Biotechnologica 22, 35-41. https://doi.org/10.1002/15213846(200205)22:1/2<35::AID-ABIO35>3.0.CO;2-U

Ekenler, M., Tabatabai, M.A., 2004. $\beta$-glucosaminidase activity as an index of nitrogen mineralization in soils. Communications in Soil Science and Plant Analysis 35(7-8), 1081-1094. https://doi.org/10.1081/CSS120030588

Flückiger, W., Braun, S., 1995. Revitalization of an alpine protective forest by fertilization. Plant Soil 168-169, 481-488. https://doi.org/10.1007/ BF00029360

Gianfreda, L., 2015. Enzymes of importance to rhizosphere processes. Journal of Soil Science and Plant Nutrition, 15(2): 283-306, https://doi. org/10.4067/s0718-95162015005000022

Hu, W., Jiao, Z., Wu, F., Liu, Y., Dong, M., Ma, X., Fan, T., An, L., Feng, H., 2014. Long-term effects of fertilizer on soil enzymatic activity of wheat field soil in Loess Plateau, China. Ecotoxicology 23(10), 2069-2080. https://doi.org/10.1007/s10646-014-1329-0

IUSS Working Group WRB, 2015. World reference base for soil resources 2014. International soil classification system for naming soils and creating legends for soil maps, World Reference Base for Soil Resources 2014, update 2015. International soil classification system for naming soils and creating legends for soil maps. World Soil Resources Reports No. 106, Rome. https://doi.org/10.1017/ S0014479706394902

Januszek, K., Wanic, T., Małek, S., Błońska, E., Jach, P., Kubala, D., 2020. Effects of magnesite fertilization on soil properties and nutrition state of weakened Norway Spruce stands in the Śnieżnik Massif of Polish Eastern Sudety Mountains. Baltic Forestry 26(1): 358. https:// doi.org/10.46490/BF358

Loeppmann, S., Semenov, M., Blagodatskaya, E., Kuzyakov, Y., 2016. Substrate quality affects microbial- and enzyme activities in rooted soil. Journal of Plant Nutrition and Soil Science 179, 39-47. https://doi. org/10.1002/jpln.201400518

Luo, P., Han, X., Wang, Y., Han, M., Shi, H., Liu, N., Bai, H., 2015. Influence of long-term fertilization on soil microbial biomass, dehydrogenase activity, and bacterial and fungal community structure in a brown soil of northeast China. Annals of Microbiology 65, 533-542. https:// doi.org/10.1007/s13213-014-0889-9

Marschner, H., 1995. Mineral nutrition of higher plants. Academic Press, San Diego, 889

Millaleo, R., Reyes-Díaz, M., Ivanov, A.G., Mora, M.L., Alberdi, M., 2010. Manganese as essential and toxic element for plants: Transport, accumulation and resistance mechanisms. Journal of Soil Science and Plant Nutrition 10(4), 476-494. https://doi.org/10.4067/S071895162010000200008

Nannipieri, P., Trasar-Cepeda, C., Dick, R.P., 2018. Soil enzyme activity: a brief history and biochemistry as a basis for appropriate interpretations and meta-analysis. Biology and Fertility of Soils 54, 11-19. https://doi.org/10.1007/s00374-017-1245-6

Parvin, S., Blagodatskaya, E., Becker, J.N., Kuzyakov, Y., Uddin, S., Dorodnikov, M., 2018. Depth rather than microrelief controls microbial biomass and kinetics of C-, N-, P- and S-cycle enzymes in peatland. Geoderma 324, 67-76. https://doi.org/10.1016/j.geoderma. 2018.03.006

Piaszczyk, W., Błońska, E., Lasota, J., 2017. Study on the effect of organic fertilizers on soil organic matter and enzyme activities of soil in forest nursery. Soil Science Annual 68(3), 125-131. https://doi.org/10.1515/ ssa-2017-0015

Porter, G.S., Bajita-Locke, J.B., Hue, N.V., Strand, D., 2004. Manganese Solubility and Phytotoxicity Affected by Soil Moisture, Oxygen Levels, and Green Manure Additions. Communications in Soil Science and Plant Analysis 35, 99-116. https://doi.org/10.1081/CSS-120027637

Pritsch, K., Raidl, S., Marksteiner, E., Blaschke, H., Agerer, R., Schloter, M., Hartmann, A., 2004. A rapid and highly sensitive method for measuring enzyme activities in single mycorrhizal tips using 4-methylumbelliferone-labelled fluorogenic substrates in a microplate system. Journal of Microbiological Methods 58, 233-241. https://doi.org/10.1016/ j.mimet.2004.04.001

Rousk, J., Bååth, E., Brookes, P.C., Lauber, C.L., Lozupone, C., Caporaso, J.G., Knight, R., Fierer, N., 2010. Soil bacterial and fungal communities across a pH gradient in an arable soil. ISME Journal 4, 1340-1351.

Saarsalmi, A., Tamminen, P., Kukkola, M., 2014. Effects of long-term fertilisation on soil properties in scots pine and Norway spruce stands. Silva Fennica 48(1), 1-19. https://doi.org/10.14214/sf.989

Saarsalmi, A., Tamminen, P., Kukkola, M., Levula, T., 2011. Effects of liming on chemical properties of soil, needle nutrients and growth of Scots pine transplants. Forest Ecology and Management 262(2), 278-285. https://doi.org/10.1016/j.foreco.2011.03.033

Sanaullah, M., Razavi, B.S., Blagodatskaya, E., Kuzyakov, Y., 2016. Spatial distribution and catalytic mechanisms of $\beta$-glucosidase activity at the root-soil interface. Biology and Fertility of Soils 52, 505-514. https:// doi.org/10.1007/s00374-016-1094-8

Schaaf, W., Hüttl, R.F., 2006. Experiences with liming in European countries - results of long-term experiments. Journal of Forest Science 52, 35-44. https://doi.org/10.17221/10158-JFS

Shaaban, M., Peng, Q., Hu, R., Wu, Y., Lin, S., Zhao, J., 2015. Dolomite application to acidic soils: a promising option for mitigating N2O emissions. Environmental Science and Pollution Research 22, 19961-19970. https://doi.org/10.1007/s11356-015-5238-4

Sienkiewicz, A., 2009: Zakwaszenie gleb leśnych w szkółkach. Wapnowanie gleb w szkółkach leśnych (Acidification of forest soil in nurseries. Liming of soil in forest nurseries). [In:]: Wesoły W., Hauke M., (Eds.) Szkółkarstwo leśne od A do Z (Forest nursery from A to Z). Centrum Informacyjne Lasów Państwowych Warszawa 2009, 94-100

Szołtyk, G., 2006. Rola wapnowania w gospodarce leśnej. Nawozy i nawożenie (The role of liming in forest management. Fertilizers and fertilization) 2(27), 104-114.

Szołtyk, G., Hilszczańska, D., 2003: Rewitalizacja gleb w szkółkach leśnych (Soil revitalization in forest nurseries). Centrum Informacyjne Lasów Państwowych, Warszawa, 1-44.

Tabatabai, M.A., 1994. Soil Enzymes, [In:] Weaver, R.W., Angle, S., Bottomley, P. (Eds.), Methods of Soil Analysis. Part 2: Microbiological and Biochemical Properties. Soil Science Society of America, Madison, pp. 775-833. https://doi.org/10.2136/sssabookser5.2.c37

Turner, B.L., 2010. Variation in pH Optima of Hydrolytic Enzyme Activities in Tropical Rain Forest Soils. Applied and Environmental Microbiology 76, 6485-6493. https://doi.org/10.1128/AEM.00560-10 
Walendziak, R.J., Szołtyk, G., 1992. Nawożenie mineralne i wapnowanie (The mineral fertilization and liming). [In:] Sobczak R. (Ed.) Szkółkarstwo leśne (Forest nursery). Wydawnictwo Świat. Warszawa 1992, s. $44-51$

van den Driessche, R., 1984. Soil Fertility in Forest Nurseries, [In:] Duryea, M.L., Landis, T.D., Perry, C.R. (Eds.), Forestry Nursery Manual:
Production of Bareroot Seedlings. Forestry Sciences, Springer, Dordrecht, pp. 63-74. https://doi.org/10.1007/978-94-009-6110-4_7

Yang, Y., He, Z., Yang, X., Fan, J., Stoffella, P., Brittain, C., 2012. Dolomite Phosphate Rock-Based Slow-Release Fertilizer for Agriculture and Landscapes. Communications in Soil Science and Plant Analysis 43:9, 1344-1362. https://doi.org/10.1080/00103624.2012.666308

\section{Słowa kluczowe}

Aktywność enzymatyczna

Nawożenie

Dolomitowanie

Właściwości gleby

Toksyczność manganu

\section{Wpływ nawożenia dolomitem na stan odżywienia sadzonek oraz właściwości gleb w szkółce leśnej}

\section{Streszczenie}

Celem przeprowadzonych badań było określenie wpływu nawożenia dolomitem na właściwości gleb na szkółce leśnej oraz określenie stanu odżywienia sadzonek dwóch gatunków: buka zwyczajnego (Fagus sylvatica L.) i dębu szypułkowego (Quercus robur L.). Badania zostały przeprowadzone na terenie szkółki leśnej w Nadleśnictwie Polanów, położonej w północnej części Polski. W celu przeprowadzenia badań założono poletka doświadczalne, na których zastosowano mineralne nawożenie dolomitem w ilości $2200 \mathrm{~kg} / \mathrm{ha}$. Rok i dwa lata po wykonaniu nawożenia została przeprowadzona ocena właściwości gleb oraz określenie zawartość składników odżywczych w liściach sadzonek badanych gatunków. W próbkach gleb zostało oznaczone pH, zawartość węgla (C) i azotu (N), zawartość kationów zasadowych, formy azotu mineralnego oraz aktywność enzymatyczna. W liściach badanych gatunków określono również zawartość makro i mikroskładników. Przeprowadzone badania potwierdziły korzystny wpływ zastosowanego nawożenia dolomitem. Wykonany zabieg nawożenia doprowadził do zmniejszenia zakwaszenia, wzrostu zawartości magnezu (Mg) oraz poprawy aktywności enzymatycznej. W przypadku obu gatunków zanotowano poprawę stanu odżywienia zarówno w rok i dwa lata od wykonania zabiegu nawożenia. Pozytywnym efektem przeprowadzonego nawożenia dolomitem było obniżenie zawartości manganu w aparacie asymilacyjnym buka i dębu. Zanotowano istotną korelację pomiędzy zawartością manganu w liściach badanych gatunków, a zawartością magnezu w glebach. Aktywność enzymatyczna gleb reaguje na zmiany właściwości gleb powodowane nawożeniem dolomitem. 